\title{
Systemic Short-Term Fibrinolysis with High-Dose Streptokinase in Acute Myocardial Infarction: Time Course of Biochemical Parameters
}

\author{
By S. W. Golf, H. Temme, K. D. Kempf $),$ H. Bleyl, A. Brüstle, \\ Zentrum für Klinische Chemie und Pathobiochemie an den Universitätskliniken \\ der Justus-Liebig-Universität Gießen,
}

\section{R. Bödeker}

Institut für Medizinische Informatik an den Universitätskliniken der Justus-Liebig-Universität Gießen and

\section{Heinrich}

Zentrum für Innere Medizin an den Universitätskliniken der Justus-Liebig-Universität Gießen

(Received July 19/October 16,1984 )

Herrn Prof. Dr. L. Róka zum 65. Geburtstag gewidmet

\begin{abstract}
Summary: The course of plasma catalytic activities of total creatine kinase, creatine kinase isoenzyme MB, total, cytoplasmatic and mitochondrial aspartate aminotransferase, alanine aminotransferase, lactate dehydrogenase, $\alpha$-hydroxybutyrate dehydrogenase, glutamate dehydrogenase and concentrations of myoglobin, urea, acidic $\alpha_{1}$-glycoprotein and creatinine were followed in 33 patients suffering from acute myocardial infarction. All patients were randomized in a double-blind, prospective study. One group (18 patients) was infused with streptokinase $1.5 \times 10^{6}$ units/90 minutes; the control group received routine continuous i.v. heparin treatment (1000 units/h). Ten hours after completion of the study protocol, treatment of both groups of patients was continued with heparin, 1000 units $/ \mathrm{h}$ and Aspisol ${ }^{\circledR}, 1 \mathrm{~g} /$ day $\left.^{2}\right)$. Streptokinase treatment induced earlier wash-out and therefore earlier peak levels of several enzymes: total creatine kinase (11 hours), creatine kinase isoenzyme MB (6 hours), total and cytoplasmatic aspartate aminotransferase (6 hours) and lactate dehydrogenase (9 hours). Total creatine kinase peak catalytic activity and myoglobin peak concentration were higher in the group receiving thrombolytic therapy. A significantly different course of catalytic activity between both treatment groups was found for total creatine kinase and creatine kinase isoenzyme $\mathrm{MB}$, total and cytosolic aspartate aminotransferase, lactate dehydrogenase and $\alpha$-hydroxybutyrate dehydrogenase. The course of mitochondrial aspartate aminotransferase catalytic activity was different only 12 hours after the beginning of treatment. The shift of several catalytic activities to an earlier peak level in plasma may indicate reperfusion of ischaemic myocardium due to thrombolytic therapy.
\end{abstract}

Systemische Kurzzeitlyse mit hochdosierter Streptokinase bei Patienten mit akutem Myokardinfarkt: Verlauf der biochemischen Kenngrößen

Zusammenfassung: Im Rahmen einer prospektiven Doppelblindstudie mit Streptokinase $\left(1,5 \times 10^{6}\right.$ Einheiten/90 Minuten) gegenüber der Kontrolle (1000 Einheiten Heparin/Stunde als Dauerinfusion) bei Patienten mit frischen Myokardinfarkt wurde der zeitliche Verlauf folgender Analyte ausgewertet: Gesamt-Kreatinki-

1) This report contains essential parts of the dissertation of $K . D$. Kempf.

$\Rightarrow 1 \mathrm{~g} \mathrm{Aspisol}{ }^{\mathbb{6}}$ (Bayer) contains $900 \mathrm{mg} \mathrm{D,L-lysine} \mathrm{mono(acetylsalicylic} \mathrm{acid)} \mathrm{(equivalent} \mathrm{to} 500 \mathrm{mg}$ acetylsalicylic acid) and $100 \mathrm{mg}$ aminoacetic acid. 
nase und Kreatinkinase-Isoenzym-MB, Gesamt-, cytoplasmatische und mitochondriale Aspartat-Aminotransferase, Alanin-Aminotransferase, Lactatdehydrogenase, $\alpha$-Hydroxybutyratdehydrogenase und Glutamatdehydrogenase sowie Myoglobin, Harnstoff, saures $\alpha_{1}$-Glycoprotein und Kreatinin im Plasma. Alle Patienten hatten randomisiert entweder Streptokinase (18 Personen) oder Heparin (15 Personen) erhalten. Die maximalen katalytischen Aktivitäten wurden in der Streptokinasegruppe bei der Gesamt-Kreatinkinase 11 Stunden, dem Kreatinkinase-Isoenzym-MB 6 Stunden, der Gesamt- und cytoplasmatischen Aspartat-Aminotransferase 6 Stunden und Lactatdehydrogenase 9 Stunden früher erreicht als in der Kontrollgruppe. Die maximale katalytische Aktivität der Gesamt-Kreatinkinase und die maximale Konzentration des Myoglobins waren im Plasma der mit Streptokinase behandelten Gruppe erhöht. Der zeitliche Verlauf der katalytischen Aktivitäten der Gesamt-Kreatinkinase und der Kreatinkinase-Isoenzym-MB, der Gesamt-, cytoplasmatischen und teilweise auch der mitochondrialen Aspartat-Aminotransferase, der Lactatdehydrogenase und $\alpha$ Hydroxybutyratdehydrogenase war in beiden Gruppen unterschiedlich. Die Verschiebung des Peaks der katalytischen Aktivitäten der Gesamt-Kreatinkinase und der Kreatinkinase-Isoenzym-MB zu einem früheren Zeitpunkt hin könnte sich zur Beurteilung der Wirkung der Streptokinase-Therapie eignen.

\section{Introduction}

The laboratory diagnosis of myocardial infarction usually involves measurement of total creatine kinase (EC 2.7.3.2) and total lactate dehydrogenase (EC 1.1.1.27) catalytic activities and evaluation of their isoenzyme fractions (1). Diagnostic criteria vary but it is generally agreed that a significant elevation of creatine kinase isoenzyme MB catalytic activity accompanied by a concomitant rise in lactate dehydrogenase isoenzyme 1 or total aspartate aminotransferase catalytic activity is pathognomonic of acute myocardial infarction (2).

Other indicators of an evolving myocardial infarction include a rise in plasma myoglobin concentration (3), in plasma urea concentration (4) reflecting the degradation of protein and in plasma concentration of the acidic $\alpha_{1}$-glycoprotein (5), an acute-phase reactant indicating muscle cell reparation (6).

Aspartate aminotransferase (EC 2.6.1.1) consists of two isoenzymes, one associated with the cytoplasma and the other with mitochondria (7). Since aspartate aminotransferase is mainly found in striated muscles, myocardium and liver, an increase in serum catalytic activity correlates with diseases of these organs (8, 9 ). The ratio of serum mitochondrial to total serum aspartate aminotransferase catalytic activity has been reported to reflect the severity of cellular damage $(9,10)$.

Modern medical treatment of acute myocardial infarction is preferentially aimed at the jeopardized myocardium surrounding the fully infarcted area. Therapeutic aims are: Decrease of $\mathrm{O}_{2}$-consumption and increase of $\mathrm{O}_{2}$-supply of the myocardial regions at risk. Besides analgesia, sedation, application of $\beta$ blocking drugs (11) and proteins such as hyaluronidase (12), decrease of preload and afterload, an ear- ly restoration of coronary blood flow by thrombolysis seems to be promising $(13,14,15)$.

Since acute results of thrombolytic treatment by intravenous application of streptokinase were not controlled by coronary angiography, we were interested to see if biochemical parameters would indicate a possible reperfusion of ischaemic myocardium.

\section{Methods}

33 patients $(31 \delta, 2 \%)$ with acute myocardial infarction were selected for this study. All patients with the following characteristics were excluded: reinfarction; age over 65 years; onset of infarction symptoms more than 6 hours before; creatine kinase catalytic activity higher than $150 \mathrm{U} / \mathrm{l}$; previous oral anticoagulation therapy; haemorrhagic diathesis; duodenal or gastric ulcer; ulcerative colitis; aortic aneurism; hypertension with systolic values higher than $200 \mathrm{~mm} \mathrm{Hg}$ and diastolic values higher than $120 \mathrm{~mm} \mathrm{Hg}$; apoplexy; status after reanimation; trauma or operation (more than 10 days before); metastatic diseases; bacterial endocarditis; pregnancy; pace maker and valvular insufficiency with continuous arrhythmia. Four to six weeks after the myocardial infarction, coronary angiograms and scintigrams were obtained from all patients. These data will not be available until the end of the stüdy.

In the double-blind randomized trial the patients received $1.5 \times$ $10^{6}$ units streptokinase (Behring Institute, D-355 Marburg) in 90 minutes or 1000 units heparin per hour. Ten hours after termination of lysis, treatment of all patients was continued with 1000 units heparin per hour i.v. and $1 \mathrm{~g}$ Aspisol ${ }^{\circledR}$ per day.

Blood samples were drawn immediately before treatment, $1.5,3$ hours and then every 3 hours for a total of 48 hours after admission to the intensive care unit. The EDTA plasma was stored at $-70^{\circ} \mathrm{C}$.

All parameters were determined within 2 weeks using an ACP 5040 (Eppendorf, D-2000 Hamburg) and commercially available test reagents for total creatine kinase and isoenzyme $\mathrm{MB}$ (immu= no-inhibition method), lactate dehydrogenase, $\alpha$-hydroxybutyrate dehydrogenase, alanine aminotransferase (EC 2.6.1.2), total and cytosolic aspartate aminotransferase," glutamate dehydrogenase 
(EC 1.4.1.3) catalytic activities, urea and creatinine concentrations. Myoglobin concentration was determined by radioimmunoassay using a kit obtained from IDW, Sprendlingen, The acidic $\alpha_{1}$-glycoprotein concentration was determined by radial immunodiffusion using Partigen plates (Behring Institute). Total and cytosolic aspartate aminotransferase and alanine aminotransferase assay samples were incubated with $233 \mu \mathrm{mo} / \mathrm{h}$ pyridoxal phosphate for 15 minutes prior to measurement of enzyme activity.

Human heart mitochondrial aspartate aminotransferase was purified and antibodies were prepared according to l.c. $(16,17)$. Cytoplasmatic aspartate aminotransferase assay samples $(200 \mu \mathrm{l})$ were incubated with $233 \mu \mathrm{mol} / /$ pyridoxal phosphate and antibody solution $(70 \mu \mathrm{l})$, containing the $35-45 \%$ ammonium sulphate precipitate of rabbit anti human heart mitochondrial aspartate aminotransferase plasma, dialyzed against $0.1 \mathrm{~mol} / \mathrm{triethan}-$ olamine buffer $\mathrm{pH} 7.4$ (inhibiting $150 \mathrm{U} / 1$ of mitochondrial aspartate aminotransferase by $95 \%$ ) for 30 minutes prior to measurement of activity. Mitochondrial aspartate aminotransferase activity was calculated from the corresponding total and cytosolic activities (16). All catalytic activities were determined at $25^{\circ} \mathrm{C}$.

The statistical calculations were carried out using the logarithmized values.

\section{Results}

The results are presented in table 1 and figures 110. The cytoplasmatic catalytic activities of creatine kinase, lactate dehydrogenase, $\alpha$-hydroxybutyrate dehydrogenase, alanine aminotransferase and aspartate aminotransferase and the concentration of myoglobin increased at a greater rate and peaked earlier in the streptokinase treated group. Significantly higher peak values were found only with the total creatine kinase catalytic activity and myoglobin con- tent, while the mean maximal value was reached significantly earlier with creatine kinase and creatine kinase isoenzyme $\mathrm{MB}$, cytosolic and total aspartate aminotransferase and lactate dehydrogenase catalytic activities (U-test from Mann-Whitney and Walter's asymptotic U-test). All cytoplasmatic proteins measured, with the exception of alanine aminotransferase and myoglobin, showed a significant difference in the course of catalytic activity or concentration in plasma (two-factorial analysis of variance with repeated measures).

Maximal total creatine kinase release was observed in the heparin group between the 3rd and 6th hour $(76.2 \mathrm{U} / \mathrm{l} \cdot \mathrm{h})$ and in the streptokinase treated group between 1.5 and 3 hours $(190 \mathrm{U} / \mathrm{l} \cdot \mathrm{h})$. Creatine kinase isoenzyme $\mathrm{MB}$ appearance in plasma was greatest in the heparin treated group between the 3rd and 6th hour $(8.8 \mathrm{U} / \mathrm{l} \cdot \mathrm{h})$ and in the streptokinase treated group between 1.5 and 3 hours $(17.1 \mathrm{U} / 1$. h). Myoglobin increase in plasma was greatest between 0 and 1.5 hours $(127.6 \mu \mathrm{g} / \mathrm{l} \cdot \mathrm{h}$ in the heparin group as compared to $191 \mu \mathrm{g} / \mathrm{l} \cdot \mathrm{h}$ in the streptokinase group).

Mitochondrial aspartate aminotransferase activity in plasma was significantly lower in the streptokinase treated patients from the 12 th to the 39 th hour after admission to the hospital (t-test).

The increase of urea and acidic $\alpha_{1}$-glycoprotein concentrations in plasma was highly significant in both groups of patients, but there was no difference in the increase comparing both treatments.

Tab. 1. Data of plasma pàrameters.

\begin{tabular}{|c|c|c|c|c|c|c|c|c|c|}
\hline & \multicolumn{5}{|c|}{ Mean of maximal values } & \multicolumn{3}{|c|}{$\begin{array}{l}\text { Time of maxima } \\
\text { (hours) }\end{array}$} & \multirow{2}{*}{$\begin{array}{l}\text { Significance (p) } \\
\text { of difference } \\
\text { in time course }\end{array}$} \\
\hline & \multicolumn{2}{|c|}{ Heparin } & \multicolumn{2}{|c|}{$\begin{array}{l}\text { Strepto- } \\
\text { kinase }\end{array}$} & & Heparin & \multicolumn{2}{|l|}{$\begin{array}{l}\text { Strepto- } \\
\text { kinase }\end{array}$} & \\
\hline Creatine kinase & 892 & $U / 1$ & 1322 & $U / 1$ & $p=0.02$ & 21 & 9 & $p=0.006$ & 0.01 \\
\hline Creatine kinase isoenzyme MB & 100 & $\mathrm{mg} / \mathrm{l}$ & 129 & $\mathrm{U} / \mathrm{I}$ & n.s. & 18 & 12 & $p=0.003$ & 0.001 \\
\hline Total aspartate aminotransferase & 160 & $\mathrm{U} / \mathrm{l}$ & 192 & $\mathrm{U} / \mathrm{l}$ & n.s. & 24 & 18 & $p=0.026$ & 0.0038 \\
\hline Cytosolic aspartate aminotransferase & 140 & $\mathrm{U} / 1$ & 182 & $\mathrm{U} / \mathrm{l}$ & n.s. & 24 & 18 & $\mathrm{p}=0.036$ & 0.0034 \\
\hline Mitochondrial aspartate aminotransferase & 17.8 & $U / 1$ & 14. & $8 \mathrm{U} / \mathrm{l}$ & n.s. & 36 & 48 & n.s. & 0.05 (12th to \\
\hline Alanine aminotransferase & 41.7 & $U / 1$ & 47 & $\mathrm{U} / \mathrm{l}$ & n.s. & 27 & 27 & n.s. & 39th hour) \\
\hline Lactate dehydrogenase & 865 & $\mathrm{U} / \mathrm{l}$ & 811 & $\mathrm{U} / \mathrm{l}$ & n.s. & 39 & 30 & $p=0.037$ & 0.019 \\
\hline$\alpha=$ Hydroxybutyrate dehydrogenase & 664 & $\mathrm{U} / 1$ & 634 & $\mathrm{U} / \mathrm{l}$ & n.s. & 39 & 30 & n.s. & 0.022 \\
\hline Myoglobin & 505 & $\mu \mathrm{g} / \mathrm{l}$ & 656 & $\mu g / 1$ & $p=0.026$ & 6 & 3 & n.s. & \\
\hline Glutamate dehydrogenase & 2.7 & $U / 1$ & 4. & $4 U / 1$ & n.s. & 42 & 48 & n.s. & \\
\hline Urea & - & & 45 & & n.s. & - & 21 & n.s. & \\
\hline Acidic $\alpha_{1}$-glycoprotein & 1570 & $\mathrm{mg} / \mathrm{l}$ & 1380 & $\mathrm{mg} / \mathrm{l}$ & n.s. & 48 & 45 & n.s. & \\
\hline Creatinine & - & & - & & & - & - & & \\
\hline
\end{tabular}

- no change in course observed, n.s. - not significant 


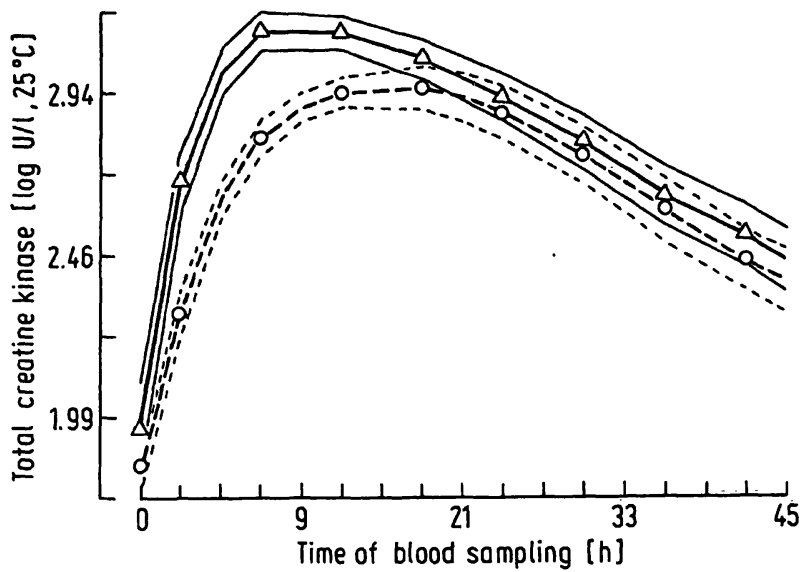

Fig. 1. Course of plasma catalytic activity of creatine kinase (log $\mathrm{U} / 1,25^{\circ} \mathrm{C}$, mean value and standard deviation) of persons suffering from a myocardial infarction. $\mathrm{O}--\mathrm{O}$ heparin treated group, $N=15 ; \Delta-\Delta$ streptokinase treated group, $\mathbf{N}=18$.

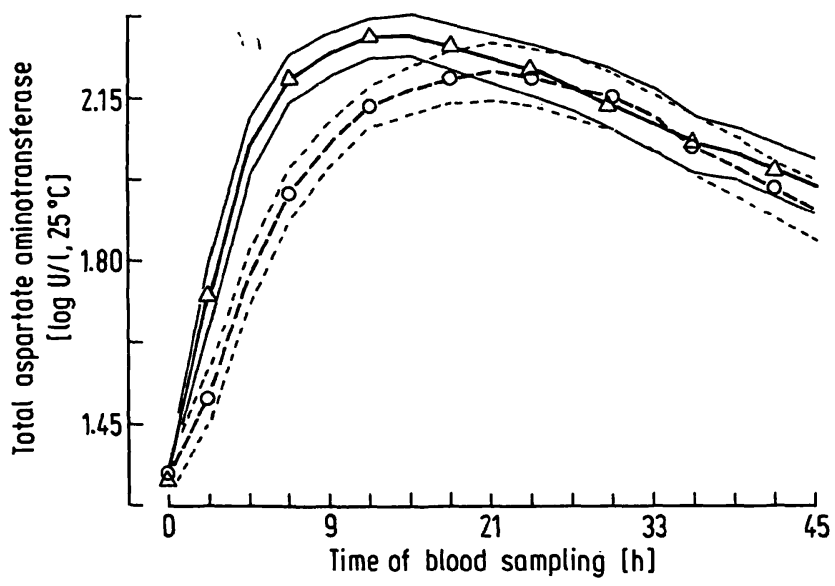

Fig. 3. Course of plasma catalytic activity of total aspartate aminotransferase $\left(\log U / 1,25^{\circ} \mathrm{C}\right.$, mean value and standard deviation) of persons suffering from a myocardial infarction. $\mathrm{O}-\mathrm{O}$ heparin treated group, $\mathrm{N}=15 ; \Delta-\Delta$ streptokinase treated group, $\mathrm{N}=18$.

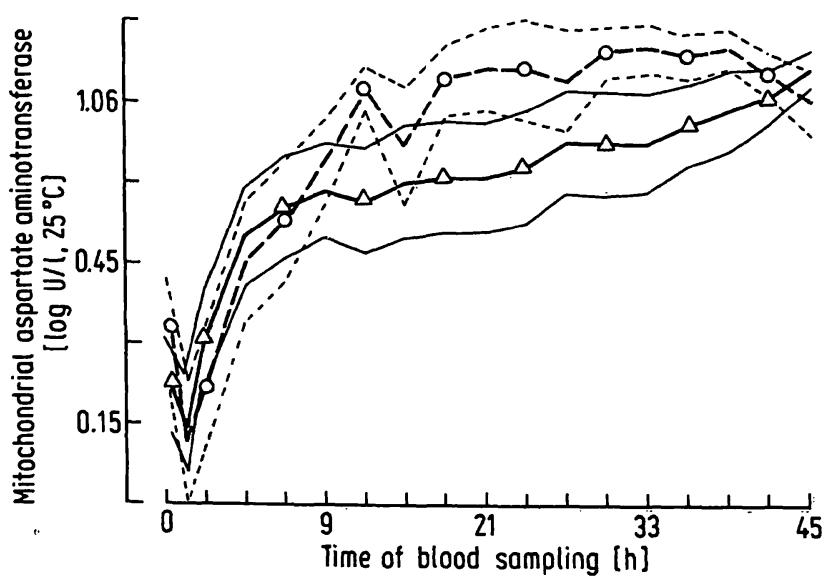

Fig. 5. Course of plasma catalytic activity of mitochondrial aspartate aminotransferase $\left(\log \mathrm{U} / 1,25^{\circ} \mathrm{C}\right.$, mean value and standard deviation) of persons suffering from a myocardial infarction. $O--O$ heparin treated group, $N=15$; $\triangle \longrightarrow$ streptokinase treated group, $\mathrm{N}=18$.

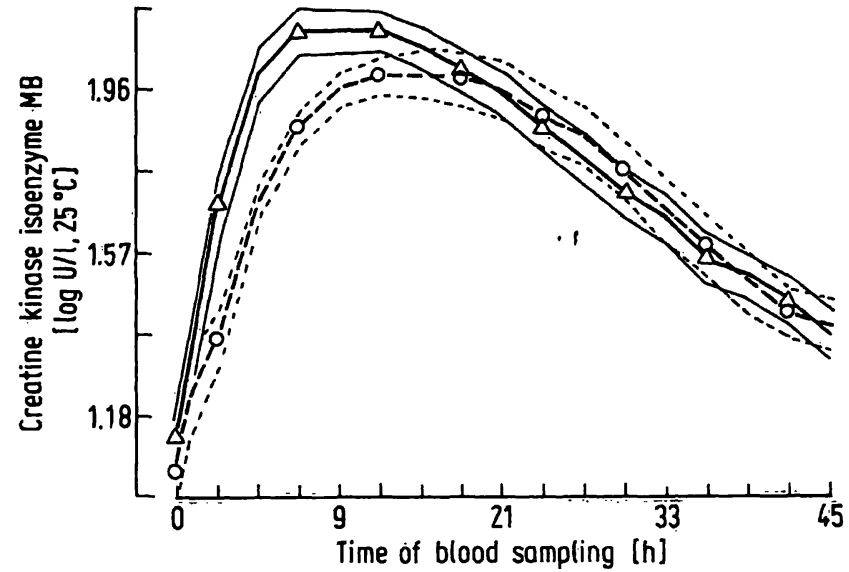

Fig. 2. Course of plasma catalytic activity of creatine kinase isoenzyme $\mathrm{MB}\left(\log \mathrm{U} / 1,25^{\circ} \mathrm{C}\right.$, mean value and standard deviation) of persons suffering from a myocardial infarction. $\mathrm{O}--\mathrm{O}$ heparin treated group, $\mathrm{N}=15 ; \Delta-\Delta$ streptokinase treated group, $\mathrm{N}=18$.

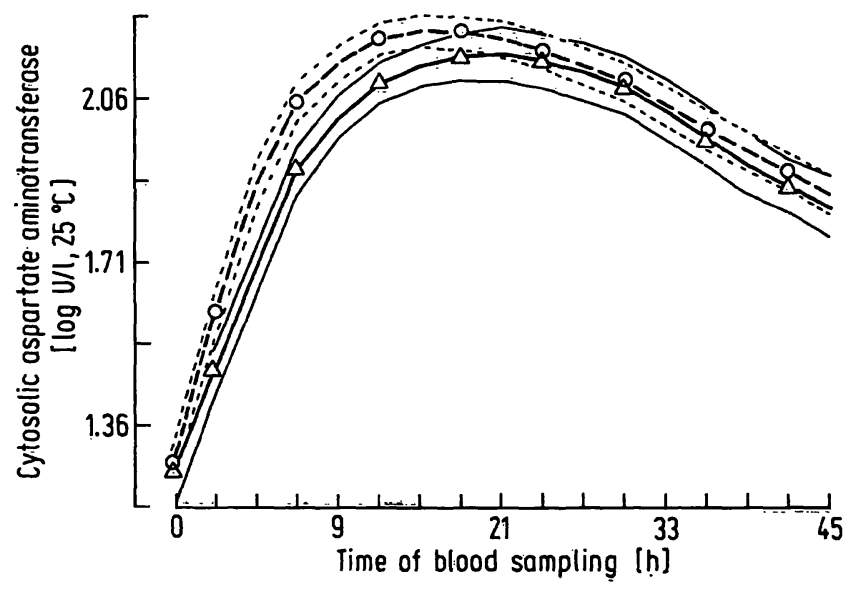

Fig. 4. Course of plasma catalytic activity of cytosolic aspartate aminotransferase $\left(\log \mathrm{U} / \mathrm{h}, 25^{\circ} \mathrm{C}\right.$, mean value and standard deviation) of persons suffering from a myocardial in farction. $\Delta-\Delta$ heparin treated group, $N=15 ; 0--O$ streptokinase treated group, $\mathbf{N}=18$.

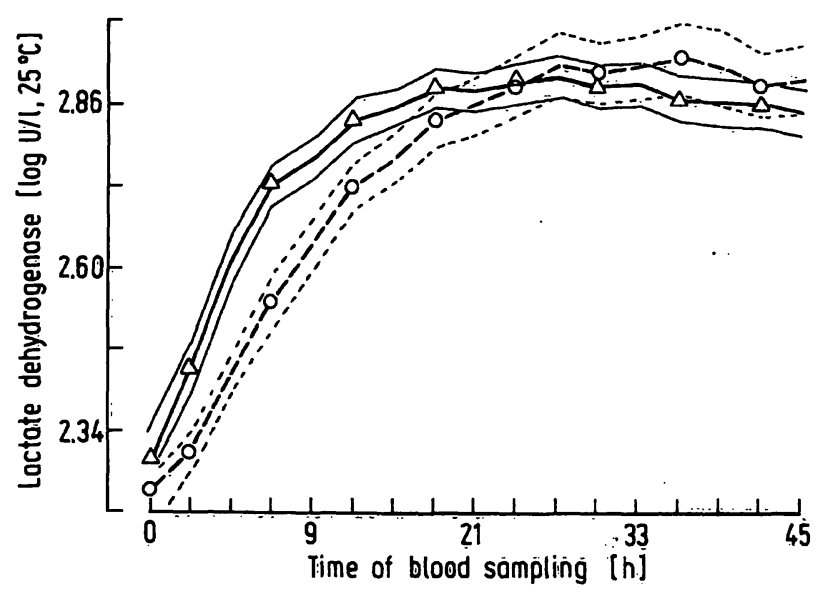

Fig. 6. Course of plasma catalytic activity of lactate dehydrogenase $\left(\log \mathrm{U} /, 25^{\circ} \mathrm{C}\right.$, mean value and standard deviation) of persons suffering from a myocardial infarction. $\mathrm{O}--\mathrm{O}$ heparin treated group, $\mathrm{N}=15 ; \Delta-\Delta$ streptokinase treated group, $\mathrm{N}=18$. 


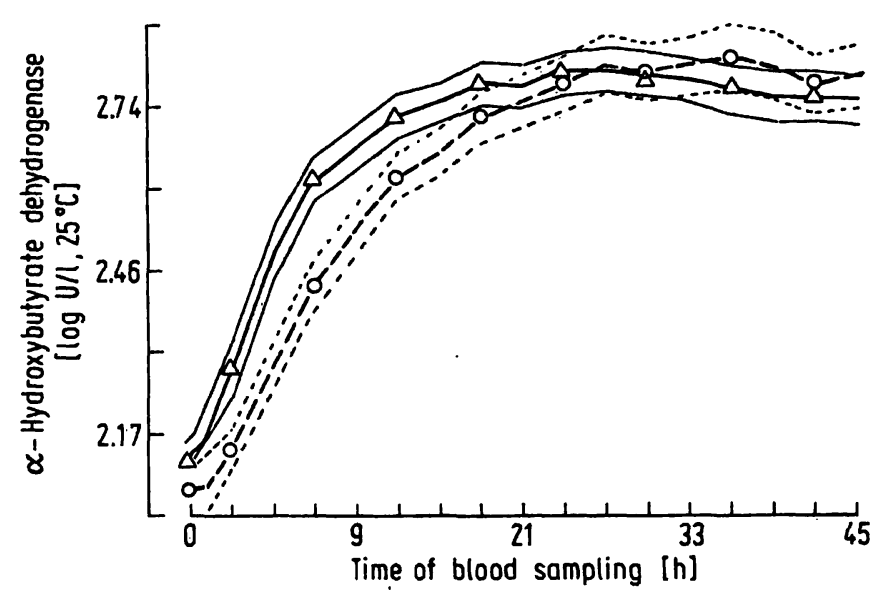

Fig. 7. Course of plasma catalytic activity of $\alpha$-hydroxybutyrate dehydrogenase $\left(\log \mathrm{U} / 1,25^{\circ} \mathrm{C}\right.$, mean value and standard deviation) of persons suffering from a myocardial infarction. $O--O$ heparin treated group, $N=15 ; \Delta-\Delta$ streptokinase treated group, $\mathrm{N}=18$.

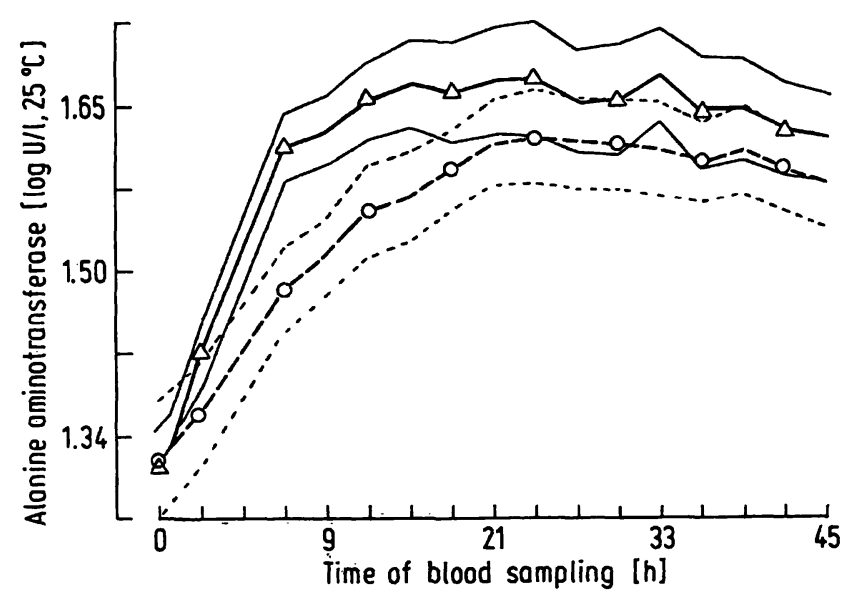

Fig. 9. Course of plasma catalytic activity of alanine aminotransferase (log U/, $25^{\circ} \mathrm{C}$, mean value and standard deviation) of persons suffering from a myocardial infarction. $\mathrm{O}--\mathrm{O}$ heparin treated group, $N=15 ; \Delta=\Delta$ streptokinase treated group, $\mathrm{N}=18$.

\section{Discussion}

The mortality of patients with acute myocardial infarction correlates well with the area of injured myocardium. It is presumed that a zone of ischaemic tissue surrounds an area of necrosis. The fate of this border zone determines the progniosis of the patient and depends on various influences of the infarcted ventricle (18), although this concept is controversial (19).

Various therapeutic attempts to limit the size of this border area and thus to reduce the severity of damage to the myocardium have been made. These include most aggressive procedures e.g. acute aortocoronary bypass operations or the attempt to establish coronary reperfusion by angioplasty (catheter

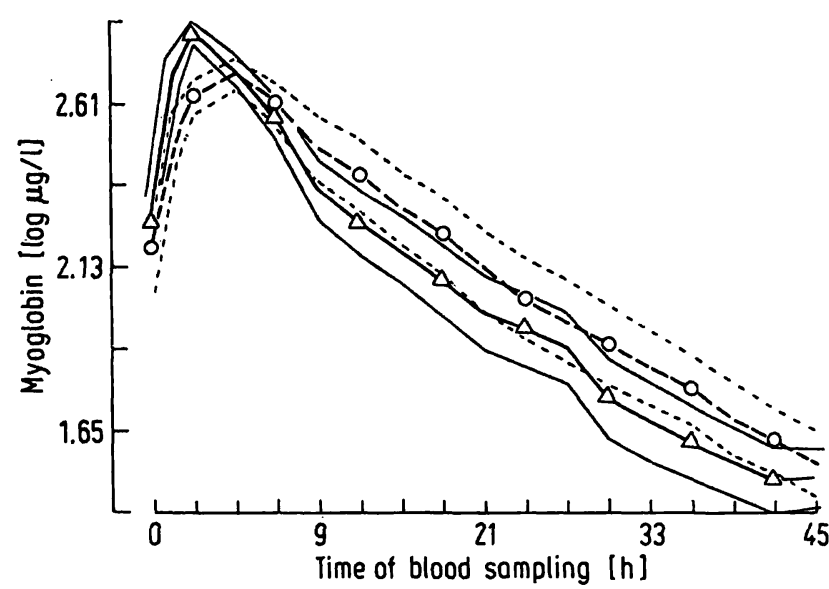

Fig. 8. Course of plasma concentration of myoglobin $(\log \mu \mathrm{g} /$, mean value and standard deviation) of persons suffering from a myocardial infarction. $\mathrm{O}--\mathrm{O}$ heparin treated group, $\mathrm{N}=15 ; \Delta-\Delta$ streptokinase treated group, $\mathrm{N}=$ 18.

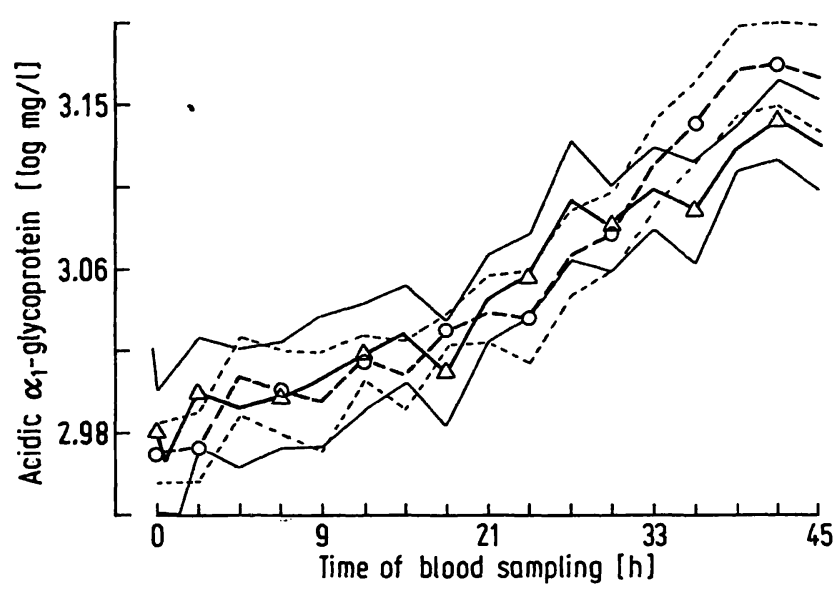

Fig. 10. Course of plasma concentration of the acidic $\alpha_{1}$-glycoprotein (log $\mathrm{mg} /$, mean value and standard deviation) of persons suffering from a myocardial infarction. $\mathrm{O}--\mathrm{O}$ heparin treated group, $N=15 ; \Delta-\Delta$ streptokinase treated group, $\mathrm{N}=18$.

dilatation of the vessel) or intracoronary application of fibrinolytic drugs. Such procedures, however, are limited to specialized centers. If the success of intravenous therapy with streptokinase could be assured the benefit of thrombolytic treatment could be extended to a much larger number of patients including those in smaller intensive care units where coronary catherization and angiography are not routinely available.

Successful intravenous treatment with streptokinase, i.e. rapid reperfusion of the occluded coronary artery, has been reported to be correlated with an increased washing-out of cytosolic enzymes from the ischaemic area, followed by an earlier appearance of these enzymes in the patient's plasma (20). 
According to this hypothesis one could say that the thrombolytic therapy of our patients was successful, if the laboratory results could be supported by clinical data. Total creatine kinase and isoenzyme $\mathrm{MB}$, total and cytosolic aspartate aminotransferase and lactate dehydrogenase peak catalytic activities occurred significantly earlier in the streptokinase treated patients. It is surprising that no such effect could be seen in myoglobin concentration which contradicts the data of Kaiser et al. (21). At the end of the study more clinical data will be available, especially on coronary angiography and scintigraphy, so that a correlation of accelerated enzyme release into the patient's plasma with clinical data will be possible.

The kinetics of cytoplasmatic enzyme appearance in plasma of streptokinase treated patients are in addition characterized by a more rapid enzyme release into the plasma, as indicated by the total creatine kinase catalytic activity $(190 \mathrm{U} / \mathrm{l} \cdot \mathrm{h}$ as compared to $76.2 \mathrm{U} / \mathrm{l} \cdot \mathrm{h}$ in the control group). As a result a higher maximal catalytic activity in plasma and a higher mean total amount of catalytic activity is observed, at least in the case of creatine kinase isoenzymes. This accords well with reports on patients having received intracoronary streptokinase treatment (22) and data obtained from dogs with reperfused and nonreperfused coronary circulation (20). These results, however, have not been confirmed unanimously (23).

The difference in course of catalytic activity cannot be explained by an alteration of enzyme elimination. In accordance with earlier reports by Anderson et al. (22) and Kwong et al. (23) we can also demonstrate that the elimination of the proteins measured is equal in both groups. As is seen in figures $1-4$ and figure 8 , the elimination of plasma catalytic activities of creatine kinase, creatine kinase isoenzyme $\mathrm{MB}$, total and cytosolic aspartate aminotransferase and of concentration of myoglobin is virtually identical for both groups. It is known that the elimination of enzymes from plasma takes place in the reticuloendothelial system during the enzyme transport in the lymph (24) and that only approximately $15 \%$ of enzyme catalytic activity released from the myocardial cells appear in the circulation (25). A consequence of increased transport of enzymes, e.g. creatine kinase, into the circulation after thrombolysis following streptokinase treatment and the unchanged elimination rate in both groups is a decrease of enzyme inactivation as indicated by a higher level of enzyme activity.

A calculation of infarction size for the assessment of the success of streptokinase treatment based on serial creatine kinase activity values as proposed by
Shell et al. (26) is not possible if all patients are placed in one group. The earlier creatine kinase appearance in plasma would lead to an overestimation of infarction size in the streptokinase treated group. Although Shell's approach is probably the best which is available at present and has evolved considerably since the initial description (27), alternative ap: proaches are necessary.

The principles developed by Shell et al. (27) have been applied to serial measurements of serum myoglobin concentration (28), but the same arguments are valid as for creatine kinase activity. A definite answer as to which enzyme activity is best suited for calculation of infarction size might be possible when the enzyme activities and biochemical data obtained are compared with the recorded ST-segment deviations of the electrocardiograms.

A successful thrombolytic therapy by streptokinase treatment should result in a decreased infarction size accompanied by an improved prognosis for the patient. The appearance of the enzymes originally located in the mitochondria of the muscle cells in the plasma has been used as an indicator of reversible cellular damage $(10,11)$. Other parameters, such as plasma urea as an indicator of protein break down (4) and acidic- $\alpha_{1}$-glycoprotein reflecting the cellular repairing mechanisms (5) have been used successfully for outcome prediction in patients suffering from acute myocardial infarction (6).

Mitochondrial aspartate aminotransferase catalytic activity, acidic $\alpha_{1}$-glycoprotein and urea concentrations in plasma were lower in the group which received streptokinase treatment, but the differences were not significant with the exception of mitochondrial aspartate aminotransferase catalytic activity between the 12th and 39th hour after admission of the patients to the hospital. This could be an indication of reduction of infarction size, but one has to be careful to omit the liver as a source of enzyme activity, as it is more slowly perfused during an acute myocardial infarction. In the study, one person (streptokinase group) with a maximum glutamate dehydrogenase catalytic activity of $100 \mathrm{U} / \mathrm{l}$ was therefore excluded from the calculations.

The course of mitochondrial aspartate aminotransferase catalytic activity corresponds to the catalytic activity profiles reported in the literature (9). We detected elevated catalytic activities of this enzyme in all patients in the study, which is an indication of improved sensitivity for determination of catalytic concentration as compared to other methods (29). The increase of aspartate aminotransferase catalytic activity from mitochondrial origin is biphasic with a 
rapid appearance of catalytic activity in plasma until 12 hours after onset of treatment and a slower increase until the end of the study ( 48 hours). This characteristic course suggests that necrosis of the cells after an acute myocardial infarction occurs in

\section{References}

1. Galen, R. S., Reiffel, J. A. \& Gambino, R. (1975) J. Am. Med. Assoc. 232, 143-147.

2. Galen, R. S. (1975) Hum. Pathol. 6, 141-155.

3. McComb, J. M., McMasters, E. A., McKenzie, G. \& Adgey, A. A. (1984) Br. Heart J. 51, 189-194.

4. Bigger, J. J., Heller, C. A., Wenger, T. L. \& Weld, F. M. (1978) Am. J. Cardiol. 42, 202-210.

5. Agostini, A., Binaghi, P. C., Radice, F. \& Stabilini, R. (1972) J. Mol. Cell Cardiol. 4, 519-524.

6. Albert, A., Harris, E. K., Chapelle, J.-P., Hinsghem, C. \& Kulbertus, E. (1984) Clin. Chem. 30, 69-76.

7. Massarat, S. \& Lang, N. (1965) Klin. Wochenschrift 43, 602-606.

8. Schmidt, E., Schmidt, W. \& Otto, P. (1967) Clin. Chim. Acta 15, 283-289.

9. Inoue, M., Hori, M., Nishimoto, Y., Fukui, S., Abe, H., Wada, H. \& Minamino, T. (1978) Br. Heart J. 40, 1251-1256.

10. Idéo, G., de Franchis, R., Bellubuono, A., Sforzini, S. \& Dioguardi, N. (1972) Z. Klin. Chem. Klin. Biochem. 10, 74-76.

11. Peter, T., Norris, R. M., Clatke, E. D., Heng, M. K., Singh, B. M., Williams, B., Howell, D. R. \& Ambler, P. (1978) Circulation 57, 1091-1095.

12. Calms, J. A., Holder, D. A., Tanser, P. \& Missirlis, E. (1982) Circulation 65, 764-771.

13. Constantini, D., Corday, E., Lang, T. W., Meerbaum, S., Brash, J., Kaplan, I., Rubins, S., Gold, H. \& Osher, J. (1975) Am. J. Cardiol. 36, 368-384.

14. Ganz, W., Buchbinder, N., Marcus, H., Mondkar, A., Maddahi, J., Charuzi, Y., O'Connor, L., Shell, W., Fishbein, M. C., Kass, R., Miyamato, A. \& Swan, H. J. (1981) Am. Heart J. $101,4-13$. two steps: rapid, obviously irreversible damage leads to an appearance of about $40 \%$ of maximal enzyme activity in the plasma and a slowly occurring cellular necrosis probably reflects the dynamic survival rate of ischaemic cells surrounding the necrotic area.

15. Rentrop, P., Blanke, H., Köstering, H. \& Karsch. K. (1980) Dtsch. Med. Wochenschrift 105, 221-228.

16. Kunz, J. (1984) Dissertation, Fachbereich Humanmedizin, Justus-Liebig-Universität Gießen, Deutschland.

17. Rej, R. (1979) Clin. Biochem. 12, 250-254.

18. Simson, M. B., Harden, W., Barlow, C. \& Harken, A. H. (1979) Circulation 60, 1151-1155.

19. Helfant, R. H., Banka, V. S. \& Bodenheimer, M. M. (1978) Am. J. Cardiol. 41, 345-347.

20. Vatner, S. F., Baig, H., Manders, W. T. \& Maroko, P. R. (1978) J. Clin. Invest. 61, 1048-1056.

21. Kaiser, H., Rumpf, K. W., Spaar, U. \& Kreuzer, H. (1984) Laboratoriumsblätter $34,17-25$.

22. Anderson, J. L., Marshall, H. W. \& Bray, B. E. (1983) New Engl. J. Med. 308, 1312-1318.

23. Kwong, T. C., Fitzpatrick, P. G. \& Rothbard, R. L. (1984) Clin. Chem. 30, 731-734.

24. Sylvén, C. (1978) Scand. J. Clin. Invest. 38, 561-565.

25. Robinson, A. K., Guepp, D. R. \& Sobel, B. E. (1975) Circulation 52 (Suppl. 11), 5.

26. Shell, W. E., Kjekshus, J. K. \& Sobel, B. E. (1971) J. Clin. Invest. 50, 2614-2625.

27. Roberts, R., Henry, P. D. \& Sobel, B. E. (1975) Circulation $52,743-754$.

28. Cairns, J. A., Missirlis, E. \& Walker, W. H. C. (1983) Clin. Chem. 29, 469-473.

29. Calva, E., Aoki, K., Delgadillo, J., Lopéz-Soriano, J. \& Christlieb, I. (1974) Am. Heart J. 87, 614-618.

\section{Dr. Sighart Golf}

Institut für Klinische Chemie

und Pathobiochemie

Fachbereich Humanmedizin

der Justus-Liebig-Universität Gießen

Klinikstraße 36

D-6300 Gießen 
